\title{
Agronomic Performance of Peach Trees Grown in Subtropical Region
}

\author{
Daniela Mota Segantini ${ }^{*}$, Sarita Leonel ${ }^{1}$, Adriana de Castro Correia da Silva ${ }^{2}$, \\ Rafael Augusto Ferraz ${ }^{1}$, Ana Karolina da Silva Ripardo ${ }^{1}$ \\ ${ }^{1}$ Department of Horticulture, Sao Paulo State University (UNESP),Botucatu, Brazil \\ ${ }^{2}$ Department of Agriculture, Mato Grosso do Sul State University (UEMS), Aquidauana, Brazil \\ Email: dani segantini@hotmail.com, sarinel@fca.unesp.br, dri ubatuba@hotmail.com, \\ rafaelferraz86@hotmail.com, karoliaagro@yahoo.com.br
}

Received 15 October 2014; revised 14 November 2014; accepted 21 November 2014

Copyright (C) 2014 by authors and Scientific Research Publishing Inc.

This work is licensed under the Creative Commons Attribution International License (CC BY).

http://creativecommons.org/licenses/by/4.0/

c) (i) Dpen Access

\begin{abstract}
Peach trees are temperate climate fruit trees most planted in subtropical and tropical regions. This advance of the peach crop is mainly due to the introduction of less cold-demanding new cultivar varieties and which require using less specific techniques, such as plant growth regulators and pruning. Within this context, the objective of this work was to evaluate phenological aspects and the yield potential of the cultivars Granada, Aurora-1, Dourado-2, Douradao, Big-Aurora, Marli and Chiripá, grafted onto the "Okinawa" rootstock, planted in the region of Sao Manuel-SP, during two cultivation cycles. The experimental design used was a completely randomized design with 7 treatments and 5 replicates, with the experimental unit represented by two plants."Granada" had early harvest in mid-September, and "Chiripá" in late November and early December, in which the former was the early-ripening cultivar and the latter was the late-ripening one. "Aurora-1" and "Dourado-2", had the highest yield values, 18.95 and 16.57 tha ${ }^{-1}$ respectively, followed by "BigAurora" with yield values of $12.13 \mathrm{t} \cdot \mathrm{ha}^{-1}$. For subtropical regions, such as São Manuel-SP, less colddemanding cultivars are recommended, such as Aurora-1, Dourado-2 and Big-Aurora. The planting of early- and late-ripening varieties, such as Granada and Chiripá, respectively, is an interesting alternative for producers wanting to scale their production.
\end{abstract}

\section{Keywords}

Phenology, Production, Buds, Cultivars, Prunuspersica

${ }^{*}$ Corresponding author.

How to cite this paper: Segantini, D.M., Leonel, S., de Castro Correia da Silva, A., Ferraz, R.A. and da Silva Ripardo, A.K. (2014) Agronomic Performance of Peach Trees Grown in Subtropical Region. American Journal of Plant Sciences, 5, 35943602. http://dx.doi.org/10.4236/ajps.2014.524375 


\section{Introduction}

Brazil is the thirteenth largest peach producer yielding 220.739 tons in an area of 20.194 ha. The main producing states are Rio Grande do Sul, Sao Paulo and Santa Catarina, accounting for 60\%, 17\% and 6\% of the national production, respectively, [1]. According to IEA [2], in the 2009 crop the peach production for domestic consumption and for the industry was of approximately 20, 500 tons in Sao Paulo, with an average yield of $43 \mathrm{~kg}$ plant $^{-1}$. The cultivation of peaches in the state of Sao Paulo increased greatly in recent decades, mainly because of new technologies and the introduction of cultivar varieties better adapted to subtropical and tropical regions. In these regions, studies of cultivar adaptation are vital for consolidating the crop.

When peach trees are grown in regions with insufficient cold winters, they may experience symptoms such as delayed and longer flowering times, lower flowering and budding percentage, and consequently reduced yields, exhibiting non-uniform and low quality fruits, are characteristics of poorly adapted plants [3].

Some cultivars required 75 - 150 hours of cold, while others require over 700 hours of cold. The most planted cultivars in Brazil require between 100 and 500 hours of cold below 7.2 ${ }^{\circ}$, accumulated from May to September, to complete the dormancy period [4].

The evaluation of the phenological and yield behavior of cultivars is a key to establishing and maintaining a culture in a particular region because it provides information about the adaptation of cultivars, helping to determine the time and intensity of management techniques such as thinning, pruning, fertilizing and harvesting.

According to Mounzer [5], the phenological calendar is essential for crop management because it allows farmers to program the specific application of fertilizers, pesticides and plant growth regulators. Numerous studies in the literature show the behavior and adaptability of peach cultivars in different environmental conditions [6]-[10].

In São Paulo, the cultivation of the Douradao, Biuti, Aurora-1, Aurora-2 and Dourado-2 cultivars prevails in the peach-producing areas of the state. However, there are no reports on the behavior of Granada, Chiripá, Marli and Big-Aurora cultivars in the region of São Manuel. However, São Paulo has several peach producing regions, such as Jaú, Botucatu, Brotas and Paranapanema. Compared to the southern states of the country these regions have a milder climate, which enables an early harvest.

Within this context, the objective of this work was to evaluate aspects related to phenological and yield performance of the cultivars Granada, Aurora-1, Dourado-2, Big-Aurora, Douradao, Marli and Chiripáin Sao Manuel-SP, in order to provide peach growers of the region and areas with similar climate, alternatives to diversify the productive matrix.

\section{Material and Methods}

This work was conducted at the Experimental Farm Sao Manuel of the School of Agricultural Sciences of UNESP, located at $22^{\circ} 44^{\prime} 28^{\prime \prime S}$ and $48^{\circ} 34^{\prime} 37^{\prime \prime}$ and $740 \mathrm{~m}$ of altitude. The climate of Sao Manuel-SP, according to the Koppen classification, is $C f a$, warm temperate (subtropical), with rainfall concentration in the months of November to April and average annual precipitation of 1.376, $70 \mathrm{~mm}$ in the municipality, with a mean temperature of the warmest month higher than $22^{\circ} \mathrm{C}$ [11]. According to Pedro Junior [12], in São Manuel and Botucatu the annual accumulation of cold hours below $7.2^{\circ} \mathrm{C}$ oscillates between 40 and 60 hours and below $13^{\circ} \mathrm{C}$ oscillates between 600 and 800 hours. The soil in the area is classified as Dystrophic Red Yellow Latosol (Oxisol) [13].

The experiment was conducted over two production cycles, 2009/2010 and 2010/2011. At the time, the plants were five years old, conducted in the bowl system, $4.0 \mathrm{~m}$ spacing between plants $\times 6.0 \mathrm{~m}$ between rows, in a non-irrigated experimental area. The experimental design used was a completely randomized design, with 7 treatments and 5 replicates, with the experimental unit represented by two plants.

“Granada”: introduced by EMBRAPA (Brazilian Company of Agricultural Research), its cold requirement is of approximately 300 hours $\left(<7.2^{\circ} \mathrm{C}\right)$. Its large fruits are firm, yellow, with slightly acidic flavor and soluble solids between $8^{\circ}$ and $11^{\circ}$ Brix. In Rio Grande do Sul, flowering occurs in August and the fruits ripen in December [14].

“Aurora-1": introduced by the Agronomic Institute of Campinas (IAC), this cultivar requires less than 200 hours of cold. Its small yellow pulp fruits are firm and sweet. The soluble solids content oscillates around $14^{\circ}$ Brix. In Rio Grande do Sul, flowering starts in August and fruit ripening in December [14].

“Dourado-2” (IAC 976-11): introduced by IAC, its large fruits are firm, juicy with yellow pulp and acidic 
sweet taste and soluble solids of up to $15^{\circ}$ Brix. The plants are vigorous and highly productive. In the state of São Paulo, the beginning of the fruit harvest occurs in November [14].

"Big-Aurora" (IAC 680-13): introduced by IAC, is an early cultivar, very vigorous and with excellent yields. It has had good yields in regions with less than 50 hours of cold accumulation. Its large fruits are oblong shaped, with firm pulp and with appropriate dual-purpose characteristics. The soluble solids content can reach up to $16^{\circ}$ Brix [15].

"Douradao": introduced by IAC, descendant of "Dourado-1", exhibits medium vigor and compact growth. Its extra large fruits with sweet-acidulous pulp ripen in mid-October, with an average content of soluble solids of $16^{\circ}$ Brix and $\mathrm{pH} 4.5$ [15].

"Marli": introduced by EMBRAPA Cascata, it needs an average of 300 hours of cold $\left(<7.2^{\circ} \mathrm{C}\right)$. Its large fruits have white semi-free pulp, with soluble solids content between $12^{\circ}$ and $14^{\circ}$ Brix. In Rio Grande do Sul flowering occurs in August and can extend up to mid-September, harvest begins in December [14].

"Chiripá": introduced by EMBRAPA, is a medium vigor cultivar and its cold demand is of 400 and 500 hours. Its medium to large fruits is firm with white flesh. The soluble solids content varies from $15^{\circ}$ to $20^{\circ}$ Brix. In Rio Grande do Sul its flowering occurs in late August and fruit ripening in January [14].

On 2009/06/20 and 2010/06/30 yield pruning was performed in all cultivars and immediately after plant dormancy was halted using a water-based solution of $0.5 \%$ hydrogen cyanamide (Dormex $\left.{ }^{\circledR}\right)+1.0 \%$ mineral oil $\left(\right.$ Assist $\left.^{\circledR}\right)$.

Phenological analyzes were performed every 3 to 4 days. Twelve $25 \mathrm{~cm}$ long mixed branches from each plant were evaluated, distributed across the circumference of the plant. The beginning of the budding and flowering stages was considered when, respectively, $5 \%$ of vegetative buds were in the green tip stage and $5 \%$ of the flowers were open. Full budding and full bloom, respectively, when $50 \%$ or more of the vegetative buds were at the green tip stage and when $50 \%$ of flowers were open. The end of each phenological phase was characterized when there were no vegetative buds sprouting or flowers open. The cycle of each cultivar was determined by monitoring 30 flowers of each plant (repetition), from anthesis to fruit ripening. The harvest time was determined by the interval between the time of the first and last harvest.

In the same branches used for the phenological analyzes, the relationship between flowering/vegetative buds and fruit retention of each cultivar was also determined, using the formulas:

$$
\begin{aligned}
& \frac{\text { flowering }}{\text { vegetative }} \text { buds }=\text { number of flower } \frac{\text { buds }}{\text { number }} \text { of vegetative buds } \\
& \% \text { retention }=\left(\text { number of fruit } \frac{\text { retained }}{\text { number }} \text { offlower buds }\right) \times 100
\end{aligned}
$$

Yield was determined by the total number of fruit harvested and kg of fruit yield per plant. The yield determined considered a stand of 417 plants ha ${ }^{-1}\left(\mathrm{t} \cdot \mathrm{ha}^{-1}\right)$.

\section{Results and Discussion}

All cultivars began sprouting before flowering had begun. During the 2009/2010 and 2010/2011 crops, "Granada" reached full bloom, respectively, at 26 and 21 days after pruning and the break of dormancy, and "Chiripá" at 42 and 45 days, the first early-ripening and second late-ripening cultivar (Table 1). As it is a less cold-demanding cultivar, "Granada" requires less accumulation of cold hours to overcome dormancy. According to Raseira [14] "Granada" is a less cold-demanding cultivar, requiring around $300 \mathrm{~h}$ below $7.2^{\circ} \mathrm{C}$, while "Chiripá" is a more cold-demanding cultivar, requiring between $400-500 \mathrm{~h}$ below $7.2^{\circ} \mathrm{C}$, and requiring greater accumulation of cold hours to overcome the dormancy period (Table 1).

In 2009 and 2010, the full flowering of the cultivars Aurora-1, Dourado-2, Big-Aurora andDouradao occurred, respectively, at 29 and 31 days after the application of hydrogen cyanamide in the third week of July (Table 1). These results are in agreement with those of Pedro Junior [16], which reported that the spontaneous flowering time of "Aurora-1", "Douradao" and "Dourado-1" is between the second and third week of July. These authors reported that for the late-ripening cultivars, such as "Marli", spontaneous flowering occurs after the first week of August, coinciding with the results achieved in our work during the two evaluation years, in which the full flowering of "Marli" occurred between the last week of July and first week of August (Table 1). 
Table 1. Budding and flowering of peach cultivars, evaluated in Sao Manuel-SP, 2009/2010 and 2010/2011.

\begin{tabular}{|c|c|c|c|c|c|c|c|}
\hline \multicolumn{8}{|c|}{ 2009/2010 Crop } \\
\hline Cultivars & $\begin{array}{c}\text { Application of } \\
\mathrm{H}_{2} \mathrm{CN}_{2}\end{array}$ & $\begin{array}{l}\text { Beginning of } \\
\text { budding }\end{array}$ & $\begin{array}{l}\text { Full } \\
\text { budding }\end{array}$ & $\begin{array}{l}\text { Beginning } \\
\text { of flowering }\end{array}$ & $\begin{array}{c}\text { Full } \\
\text { flowering }\end{array}$ & $\begin{array}{l}\text { End of } \\
\text { flowering }\end{array}$ & $\begin{array}{c}\text { Duration of } \\
\text { flowering (days) }\end{array}$ \\
\hline Granada & 19 June & 26 June & 03 July & 03 July & 14 July & 24 July & 21 \\
\hline Aurora-1 & 19 June & 30 June & 08 July & 08 July & 17 July & 31 July & 23 \\
\hline Dourado-2 & 19 June & 30 June & 08 July & 08 July & 17 July & 31 July & 23 \\
\hline Big-Aurora & 19 June & 30 June & 17 July & 08 July & 17 July & 31 July & 23 \\
\hline Douradao & 19 June & 03 July & 17 July & 14 July & 17 July & 28 July & 14 \\
\hline Marli & 19 June & 03 July & 21 July & 14 July & 21 July & 31 July & 17 \\
\hline Chiripá & 19 June & 24 July & 31 July & 24 July & 31 July & 28 Ago. & 33 \\
\hline \multicolumn{8}{|c|}{ 2010/2011 Crop } \\
\hline Cultivars & $\begin{array}{c}\text { Application of } \\
\mathrm{H}_{2} \mathrm{CN}_{2}\end{array}$ & $\begin{array}{l}\text { Beginning of } \\
\text { budding }\end{array}$ & $\begin{array}{c}\text { Full } \\
\text { budding }\end{array}$ & $\begin{array}{l}\text { Beginning of } \\
\text { flowering }\end{array}$ & $\begin{array}{c}\text { Full } \\
\text { flowering }\end{array}$ & $\begin{array}{c}\text { End } \\
\text { of flowering }\end{array}$ & $\begin{array}{c}\text { Duration of } \\
\text { flowering (days) }\end{array}$ \\
\hline Granada & 30 June & 10 July & 17 July & 17 July & 21 July & 28 July & 11 \\
\hline Aurora-1 & 30 June & 10 July & 17 July & 17 July & 31 July & 07 Ago. & 20 \\
\hline Dourado-2 & 30 June & 10 July & 17 July & 17 July & 31 July & 07 Ago. & 20 \\
\hline Big-Aurora & 30 June & 10 July & 17 July & 17 July & 31 July & 07 Ago. & 20 \\
\hline Douradao & 30 June & 15 July & 29 July & 15 July & 31 July & 14 Ago. & 30 \\
\hline Marli & 30 June & 15 July & 29 July & 15 July & 07 Ago. & 21 Ago. & 36 \\
\hline Chiripá & 30 June & 08 July & 14 Ago. & 07 Ago. & 14 Ago. & 31 Ago. & 24 \\
\hline
\end{tabular}

In the present work, the harvest period ranged from 4 to 24 days in 2009 and 11 to 26 days in 2010, respectively, for "Douradao" and "Chiripá" (Table 1), these results are consistent with those of Pereira [17] which reported intervals of 17 and 30 days respectively in 2006 and 2007, for the Aurora-1 cultivar, grown in the region of Vista Alegre of Alto-SP. It is emphasized that climate change, pruning cultivation techniques and the application of plant growth regulators can influence the duration of the harvest period.

During the two evaluation years, "Granada" proved to be the earliest-ripening one among the cultivars studied, with its harvest period between late September and mid-October, and with the possibility of being sold before the harvest peak of the Southern regions, occurring in the months of November and December. "Chiripá" was the latest-ripening cultivar, with its harvest interval between late November and late December (Table 2). According to Nunes [18], in Rio Grande do Sul, the harvest peak of the "Chiripá" fruits occurs in the first weeks of January. The early harvest of the "Chiripá" fruits in São Manuel-SP can be explained by climatic differences between the two regions, since in mild winter regions there is flowering anticipation and reduction of the cycle.

According to the Bruna classification [19], for peach trees cultivated in sub-tropical regions, "Granada" can be classified as a short cycle cultivar because it has a cycle of 78 and 84 days, "Aurora-1", "Dourado-2", "BigAurora", "Douradão" and "Marli" as medium-cycle cultivars, because they have a cycle of 95 and 106 days (Table 2), and "Chiripá" as a long-cycle cultivar because its cycle is of 120 days and longer, in the region of Sao Manuel-SP.

During the two evaluation years, the relationship between flowering and vegetative buds ranged between 1.46 (Marli) and 2.27 (Douradão) (Table 3). "Aurora-1" showed a relation of 2.22 in 2009 and 2.20 in 2010, higher values than those found for the same cultivar by Pereira [17], of 1.28 in 2005 and of 1.17 in 2006. According to these authors, the relationship between flowering and vegetative buds influences the production of leaves and buds, and are important features related to the photosynthetic capacity of the plant and fruit growth. 
Table 2. Harvest period and cycle of peach cultivars evaluated in São Manuel-SP, during the 2009/2010 and 2010/2011 crops.

\begin{tabular}{|c|c|c|c|c|c|}
\hline \multicolumn{6}{|c|}{ 2009/2010 Crop } \\
\hline Cultivars & Beginning of harvest & Harvest peak & End of harvest & Harvest range (days) & Cycle (days) \\
\hline Granada & 20 Sep. & 28 Sep. & 06 Oct. & 16 & 84 \\
\hline Aurora-1 & 14 Oct. & 21 Oct. & 30 Oct. & 16 & 98 \\
\hline Dourado-2 & 21 Oct. & 28 Oct. & 04 Nov. & 13 & 105 \\
\hline Big-Aurora & 28 Oct. & 28 Oct. & 04 Nov. & 06 & 105 \\
\hline Douradão & 30 Oct. & 04 Nov. & 04 Nov. & 04 & 105 \\
\hline Marli & 28 Oct. & 30 Oct. & 04 Nov. & 06 & 103 \\
\hline Chiripá & 26 Nov. & 15 Dec. & 20 Dec. & 24 & 121 \\
\hline \multicolumn{6}{|c|}{2010 /2011 Crop } \\
\hline Cultivars & Beginning of harvest & Harvest peak & End of harvest & Harvest range (days) & Cycle (days) \\
\hline Granada & 25 Sep. & 02 Oct. & 16 Oct. & 22 & 80 \\
\hline Aurora-1 & 21 Oct. & 28 Oct. & 05 Nov. & 15 & 95 \\
\hline Dourado-2 & 28 Oct. & 01 Nov. & 12 Nov. & 14 & 102 \\
\hline Big-Aurora & 28 Oct. & 01 Nov. & 12 Nov. & 14 & 101 \\
\hline Douradão & 01 Nov. & 08 Nov. & 12 Nov. & 11 & 101 \\
\hline Marli & 01 Nov. & 08 Nov. & 17 Nov. & 16 & 106 \\
\hline Chiripá & 10 Dec. & 20 Dec. & 05 Jan. & 26 & 123 \\
\hline
\end{tabular}

Cycle $=$ period between beginning of flowering and fruit harvest.

Table 3. Number of flower and vegetative buds on $25 \mathrm{~cm}$ long branches, relationship between flower (GF) and vegetative buds (GE), and effective fruit retentions of peach cultivars, Sao Manuel-SP, 2009/2010 and 2010/2011.

\begin{tabular}{ccccccccc}
\hline \multirow{2}{*}{ Cultivars } & \multicolumn{2}{c}{ Flower buds } & \multicolumn{2}{c}{ Vegetative buds } & \multicolumn{2}{c}{ GF/GV relationship } & \multicolumn{2}{c}{ Fruit retention (\%) } \\
& 2009 & 2010 & 2009 & 2010 & 2009 & 2010 & 2009 & 2010 \\
\hline Granada & $14.66 \mathrm{cA}$ & $16.32 \mathrm{cA}$ & $9.33 \mathrm{aA}$ & $10.02 \mathrm{aA}$ & $1.57 \mathrm{cA}$ & $1.62 \mathrm{cA}$ & $24.85 \mathrm{cA}$ & $28.98 \mathrm{cA}$ \\
Aurora-1 & $24.33 \mathrm{aA}$ & $23.32 \mathrm{aA}$ & $11.00 \mathrm{aA}$ & $10.56 \mathrm{aA}$ & $2.22 \mathrm{aA}$ & $2.20 \mathrm{aA}$ & $50.97 \mathrm{bB}$ & $78.32 \mathrm{aA}$ \\
Dourado-2 & $20.00 \mathrm{bA}$ & $18.76 \mathrm{bA}$ & $10.33 \mathrm{aA}$ & $9.67 \mathrm{aA}$ & $1.94 \mathrm{aA}$ & $1.94 \mathrm{aA}$ & $75.46 \mathrm{aA}$ & $80.33 \mathrm{aA}$ \\
Big-Aurora & $19.66 \mathrm{bA}$ & $18.88 \mathrm{bA}$ & $9.66 \mathrm{aA}$ & $8.98 \mathrm{aA}$ & $2.03 \mathrm{bA}$ & $2.10 \mathrm{bA}$ & $72.24 \mathrm{aA}$ & $75.56 \mathrm{aA}$ \\
Douradão & $20.33 \mathrm{bA}$ & $18.34 \mathrm{bA}$ & $9.00 \mathrm{aA}$ & $8.07 \mathrm{aA}$ & $2.27 \mathrm{aA}$ & $2.27 \mathrm{aA}$ & $35.68 \mathrm{cB}$ & $49.56 \mathrm{bA}$ \\
Marli & $15.00 \mathrm{cA}$ & $14.45 \mathrm{cA}$ & $9.66 \mathrm{aA}$ & $9.88 \mathrm{aA}$ & $1.55 \mathrm{cA}$ & $1.46 \mathrm{cA}$ & $25.02 \mathrm{cA}$ & $23.98 \mathrm{cA}$ \\
Chiripá & $23.33 \mathrm{aA}$ & $22.28 \mathrm{aA}$ & $10.66 \mathrm{aA}$ & $10.22 \mathrm{aA}$ & $2.19 \mathrm{aA}$ & $2.18 \mathrm{aA}$ & $11.60 \mathrm{dA}$ & $10.88 \mathrm{dA}$ \\
$\begin{array}{c}\text { Overall } \\
\text { average }\end{array}$ & 19.91 & 18.90 & 9.95 & 9.62 & 1.96 & 1.97 & 42.26 & 49.65 \\
C.V. (\%) & 7.86 & 8.78 & 8.20 & 8.02 & 7.17 & 8.88 & 16.43 & 12.45 \\
\hline
\end{tabular}

Means followed by the same lowercase letter in the column and uppercase letter on the line, do not differ significantly by the Scott-Knott test (p < 0.05 ). Yield considering a stand of 417 plants ha $^{-1}$.

The percentage of fruit retention in the cultivars ranged from $11.60 \%$ to $75.46 \%$ in 2009 and from $10.88 \%$ to 80.33\% in 2010, respectively, for the Chiripá and Dourado-2 cultivars (Table 3). 
The results achieved in our study are consistent with those found by Alves [10], which evaluated different peach cultivars and found that the effective fruit rate ranged from 33\% (BRS Leonense) to $88.9 \%$ (Coral) in 2009; from 11.3\% (Chiripá) to $80.7 \%$ (Chimarrita) in 2010, and from $12.3 \%$ (Chiripá) to $74.6 \%$ (Chimarrita) in 2011.

"Chiripá", "Marli" and "Granada" had the lowest fruit retention rates, between 10.88 and 28.98\% in 2009 and 2010 (Table 3). The low fruit retention percentage for these cultivars may be due to failing to adapt to the region or due to genetic characteristics. According to Nava [6], the "Granada" cultivar variety is highly sensitive to high temperatures during pre-flowering and flowering, with fruit retention values ranging between 3.65 and $8.04 \%$ in the region of Pelotas-RS, when the plants were subjected to treatments to break dormancy and the application of boron during flowering. According to these authors, the fruit retention percentage can be influenced by genetic, nutritional and environmental factors. In our work, high rainfall rates were recorded in 2009 for the months of June, July and August (Figure 1), coinciding with the flowering period, in 2010 were recorded low rainfall rates at the same season (Figure 2). Pollination by bees and other insects is compromised under high rainfall rates, justifying the lower percentages of fruit retention in 2009, when compared to the retention values in 2010 (Table 3).

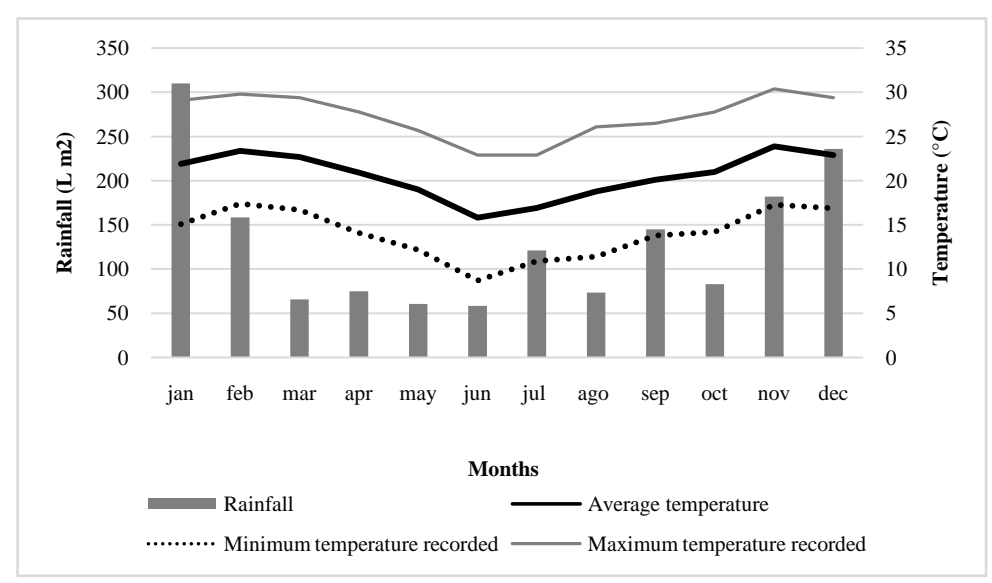

Figure 1. Rainfall $\left(\mathrm{L} \cdot \mathrm{m}^{2}\right)$, average monthly temperatures $\left({ }^{\circ} \mathrm{C}\right)$, minimum temperature recorded, maximum temperature recorded, during 2009 in Sao Manuel-SP. Data provided by the Department of Environmental Sciences/FCA/ UNESP/Botucatu, 2009.

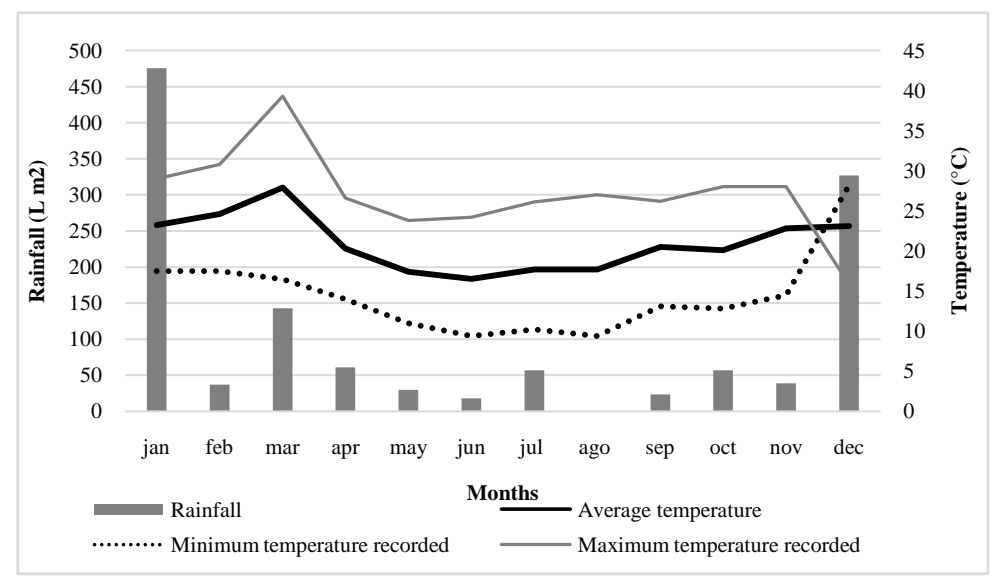

Figure 2. Rainfall $\left(\mathrm{L} \cdot \mathrm{m}^{2}\right)$, average temperature $\left({ }^{\circ} \mathrm{C}\right)$, minimum temperature recorded, maximum temperature recorded $\left({ }^{\circ} \mathrm{C}\right)$, during 2010 in Sao ManuelSP. Data provided by the Department of Environmental Sciences/FCA/UNESP/ Botucatu, 2010. 
The 2010/2011 crop harvest showed significant yield increases for the Aurora-1, Big-Aurora and Douradao cultivars, compared to the 2009/2010 harvest. The other cultivars maintained their yield values (Table 4).

"Aurora-1" had the highest yields, of $15.41 \mathrm{t} \cdot \mathrm{ha}^{-1}$ and $22.50 \mathrm{t} \cdot \mathrm{ha}^{-1}$, respectively, in 2009 and 2010 (Table 4). Higher values than those found by Pereira [17] in the region of Vista Alegre do Alto-SP, which for "Aurora-1" achieved yields of $9.15 \mathrm{t} \cdot \mathrm{ha}^{-1}$ in 2005 and $4.72 \mathrm{t} \cdot \mathrm{ha}^{-1}$ in 2006."Granada” yielded $8.83 \mathrm{~kg} \cdot \mathrm{plant}^{-1}$ in 2009 and $11.46 \mathrm{~kg} \cdot$ plant $^{-1}$ in 2010 (Table 4) and are within the values found in the literature. Rossi [20] reported that yield variations may be related to the rootstock/pruning combination, "Granada grafted on "Okinawa" yielded $0.93 \mathrm{t} \cdot \mathrm{ha}^{-1}$ when grafted on "Pavia Moscatel" under the conditions of Pelotas-RS.

Nava [6] found that boron application in this cultivar during full flowering had a yield increase of $12.69 \mathrm{~kg}$ to $35.26 \mathrm{~kg} \cdot$ plant $^{-1}$, when dormancy was halted in early July, indicating that performance can be improved in the cultivar. The lack of cold in some years, frequent oscillations and possible nutritional deficiencies could compromise the development of the buds and overcoming dormancy [7].

The lowest yield values were for "Marli" and "Chiripá", of 1.93 and 1.64 ton'ha ${ }^{-1}$, respectively, in 2009, and of 1.97 and 1.40 ton $\cdot \mathrm{ha}^{-1}$, in 2010 (Table 4), lower than those found by Nunes [18], which yielded 18.1 ton $\cdot \mathrm{ha}^{-1}$ and 20.4 ton $\cdot \mathrm{ha}^{-1}$, in the plants of the Marli cultivar grown in integrated production and conventional production system, respectively, in the region of Eldorado do Sul, RS. The differences in yield values can be explained by the climate difference between the two regions, the more intense winter cold conditions in RS which clearly provided better flowering and budding conditions, hence higher yields.

The importance of breaking dormancy in the subtropical regions is emphasized, considering that quite often the cold hours needed are not fully satisfied, requiring to use compensating chemicals. The artificial breaking of dormancy, alone or combined with short pruning, increases the percentage of flowering, effective fructification and plant yields of the Granada cultivar [21].

\section{Conclusions}

Of the cultivars evaluated, "Granada" is the earliest-ripening cultivar, with harvest in mid-September, and "Chiripá" the latest-ripening one, with harvest in late November.

"Dourado-2", "Big-Aurora" and "Aurora-1" exhibit the highest fruit retention percentage, "Marli" and "Chiripá" the lowest, and these results influence the yield values of the cultivars.

"Aurora-1" and "Dourado-2" are the most adapted and productive cultivars, hence suitable for peach cultivation in the region of São Manuel-SP.

"Chiripá", "Marli", "Granada” and "Douradao" exhibited the lowest yield potential for the region of São Manuel and require a longer evaluation period and improvement of cultivation technologies.

Table 4. Number of fruits per plant, production and yield of peach cultivars in Sao Manuel-SP, during the crops of 2009/2010 and 2010/2011.

\begin{tabular}{ccccccc}
\hline Cultivars & \multicolumn{2}{c}{ Number of fruits (unit·plant ${ }^{-1}$ ) } & \multicolumn{2}{c}{ Production $\left(\mathrm{kg} \cdot \mathrm{plant}^{-1}\right.$ ) } & \multicolumn{2}{c}{${\text { Yield }\left(\mathrm{t} \cdot \mathrm{ha}^{-1} \text { ) }\right.}^{2}$} \\
& $2009 / 2010$ & $2010 / 2011$ & $2009 / 2010$ & $2010 / 2011$ & $2009 / 2010$ & $2010 / 2011$ \\
\hline Granada & $83.33 \mathrm{cB}$ & $179.66 \mathrm{cA}$ & $8.83 \mathrm{cA}$ & $11.46 \mathrm{dA}$ & $3.68 \mathrm{cA}$ & $4.78 \mathrm{dA}$ \\
Aurora-1 & $475.00 \mathrm{aB}$ & $840.66 \mathrm{aA}$ & $36.95 \mathrm{aB}$ & $53.96 \mathrm{aA}$ & $15.41 \mathrm{aB}$ & $22.50 \mathrm{aA}$ \\
Dourado-2 & $428.33 \mathrm{aA}$ & $454.66 \mathrm{bA}$ & $39.06 \mathrm{aA}$ & $40.47 \mathrm{bA}$ & $16.28 \mathrm{aA}$ & $16.87 \mathrm{bA}$ \\
Big-Aurora & $253.66 \mathrm{bB}$ & $444.33 \mathrm{bA}$ & $21.56 \mathrm{bB}$ & $36.78 \mathrm{bA}$ & $8.92 \mathrm{bB}$ & $15.34 \mathrm{bA}$ \\
Douradão & $60.66 \mathrm{cB}$ & $240.33 \mathrm{cA}$ & $5.75 \mathrm{cB}$ & $21.85 \mathrm{cA}$ & $2.39 \mathrm{cB}$ & $9.11 \mathrm{cA}$ \\
Marli & $42.33 \mathrm{cA}$ & $44.01 \mathrm{cA}$ & $4.63 \mathrm{cA}$ & $3.93 \mathrm{eA}$ & $1.93 \mathrm{cA}$ & $1.64 \mathrm{eA}$ \\
Chiripá & $35.33 \mathrm{cA}$ & $23.33 \mathrm{dA}$ & $4.72 \mathrm{cA}$ & $3.36 \mathrm{eA}$ & $1.97 \mathrm{cA}$ & $1.40 \mathrm{eA}$ \\
Overall average & 196.94 & 257.83 & 17.36 & 20.95 & 7.22 & 8.73 \\
C.V. (\%) & 20.18 & 15.79 & 19.33 & 15.67 & 19.33 & 15.67 \\
\hline
\end{tabular}

Means followed by the same lowercase letter in the column and uppercase letter on the line, do not differ significantly by the Scott-Knott test (p < 0.05 ). Yield considering a stand of 417 plants $\cdot \mathrm{ha}^{-1}$. 


\section{Acknowledgements}

The authors are grateful to FAPESP (Fundaçao de Amparo à Pesquisa do Estado de Sao Paulo) for providing the Masters scholarship. Process: 08/52535-7; and to the staff of São Manuel Experimental Farm for their support in conducting the experiment.

\section{References}

[1] AGRIANUAL (2013) Anuário da Agricultura Brasileira, Pêssego. 18th Edition, AgraFNT, Sao Paulo, 401-407.

[2] Instituto de Economia Agrícola (2013) Produçao e número de plantas de videira no Estado de São Paulo: Disponível. http://www.iea.sp.gov.br

[3] Citadin, F., Bassani, M.H., Danner, M.A., Mazaro, S.M. and Gouvêa, A. (2006) Uso de cianamida hidrogenada e óleo mineral na floração, brotação e produção do pessegueiro "Chiripá”. Revista Brasileira de Fruticultura, 28, 32-35. http://dx.doi.org/10.1590/S0100-29452006000100012

[4] Caramori, P.H, Aviglione, J.H., Wrege, M.S., Herter, F.G., Hauagge, R., Gonçalves, S.L., Citadin, I. and Ricce, W.S. (2008) Zoneamento agroclimático para o pessegueiro e a nectarineira no estado do Paraná. Revista Brasileira de Fruticultura, 30, 1040-1044. http://dx.doi.org/10.1590/S0100-29452008000400033

[5] Mounzer, O., Conejero, W., Nicolas, E., Abrisqueta. I, García-Orellana, Y.V., Tapia, L.M., Vera, J., Abrisquesta, J.M. and Ruíz-Sánchez, M.C.G. (2008) Growth Pattern and Phenological Stages of Early-maturing Peach Trees under a Mediterranean Climate. Hortscience, 43, 1813-1818.

[6] Nava, G.A., Dalmago, G.A., Bergamaschi, H. and Marodin, G.A.B. (2009) Fenologia e produção de pessegueiros “Granada” com aplicação de cianamida hidrogenada e boro. Revista Brasileira de Fruticultura, 31, 297-304. http://dx.doi.org/10.1590/S0100-29452009000200003

[7] Nava, G.A., Marodin, G.A.B., Santos, R.P., Paniz, R., Bergamaschi, H. and Dalmago, G.A. (2011) Desenvolvimento floral e produção de pessegueiros "granada" sob distintas condições climáticas. Revista Brasileira de Fruticultura, 33, 472-481. http://dx.doi.org/10.1590/S0100-29452011005000065

[8] Leonel, S. and Tecchio, M.A. (2011) Produção e sazonalidade de pessegueiro e nectarineira sob florescimento espontâneo e com cianamida hidrogenada e óleo mineral. Revista Brasileira de Fruticultura, 33, 227-234. http://dx.doi.org/10.1590/S0100-29452011000500027

[9] Leonel, S., Pierozzi, C.G. and Tecchio, MA. (2011) Produção e qualidade de frutos de pessegueiro e nectarineira em clima subtropical do Estado de São Paulo. Revista Brasileira de Fruticultura, 33, 118-128. http://dx.doi.org/10.1590/S0100-29452011005000043

[10] Alves, G., Silva, J., Mio, L.L.M. and Biasi, L.A. (2012) Comportamento fenológico e produtivo de cultivares de pessegueiro no Município da Lapa, Paraná. Pesquisa Agropecuária Brasileira, 47, 1596-1604. http://dx.doi.org/10.1590/S0100-204X2012001100006

[11] Cunha, A.R. and Matins, D. (2009) Classificação climática para os municípios de Botucatu e São Manuel, SP. Irriga, 14, 1-11.

[12] Pedro Júnior, M.J., Ortolani, A.A., Rigitano, O., Alfonsi, R.R., Pinto, H.S. and Brunini, O. (1979) Estimativa de horas de frio abaixo de 7 e $13^{\circ} \mathrm{C}$ para a regionalização da fruticultura de clima temperado no estado de São Paulo. Bragantia, 38, 123-130. http://dx.doi.org/10.1590/S0006-87051979000100013

[13] Embrapa (2006) Centro Nacional de Pesquisa de Solos. Sistema Brasileiro de Classificação de Solos. 2nd Edition, Embrapa Solos, Rio de Janeiro.

[14] Raseira, M.C.B. and Nakasu, B.H. (1998) Cultivares. In: Medeiros, C.A.B. and Raseira, M.C.B., Eds., A cultura do pessegueiro, Embrapa-SPI, Brasília; Embrapa-CPACT, Pelotas, 29-98.

[15] Barbosa, W. (2010) Características do cultivar.

[16] Pedro Júnior, M.J., Barbosa, W., Rolim, G.S. and Castro, J.L. (2007) Época de florescimento e horas de frio para pessegueiros e nectarineiras. Revista Brasileira de Fruticultura, 29, 425-430. http://dx.doi.org/10.1590/S0100-29452007000300005

[17] Pereira, F.M. and Mayer, N.A. (2008) Frutificação, características físicas de frutos e produtividade em cultivares e seleções de pessegueiro em Vista Alegre do Alto-SP. Ciência Rural, 38, 1547-1552. http://dx.doi.org/10.1590/S0103-84782008000600009

[18] Nunes, J.L.S., Guerra, D.S., Zanini, C., Grasselli, V., Argenta, F., Facchin, H. and Marodin, G.A.B. (2004) Produção integrada e convencional de pêssegos cv. Marli. Revista Brasileira de Fruticultura, 26, 478-481. http://dx.doi.org/10.1590/S0100-29452004000300025

[19] Bruna, E.D. (2007) Curva de crescimento de frutos de pêssego em regiões subtropicais. Revista Brasileira de Fruti- 
cultura, 29, 685-689. http://dx.doi.org/10.1590/S0100-29452007000300050

[20] Rossi, A., Fachinello, J.C., Rufato, L., Parisoto, E., Picolotto, L. and Kruger, L.R. (2004) Comportamento do pessegueiro “Granada” sobre diferentes porta-enxertos. Revista Brasileira de Fruticultura, 26, 446-449. http://dx.doi.org/10.1590/S0100-29452004000300018

[21] Locatelli, M.C., Nava, G.A., Citadin, I. and Pichler, M. (2012) Fenologia e frutificação do pessegueiro “Granada” sob diferentes práticas de manejo. Revista Ceres, 59, 684-688. http://dx.doi.org/10.1590/S0034-737X2012000500014 
Scientific Research Publishing (SCIRP) is one of the largest Open Access journal publishers. It is currently publishing more than 200 open access, online, peer-reviewed journals covering a wide range of academic disciplines. SCIRP serves the worldwide academic communities and contributes to the progress and application of science with its publication.

Other selected journals from SCIRP are listed as below. Submit your manuscript to us via either submit@scirp.org or Online Submission Portal.
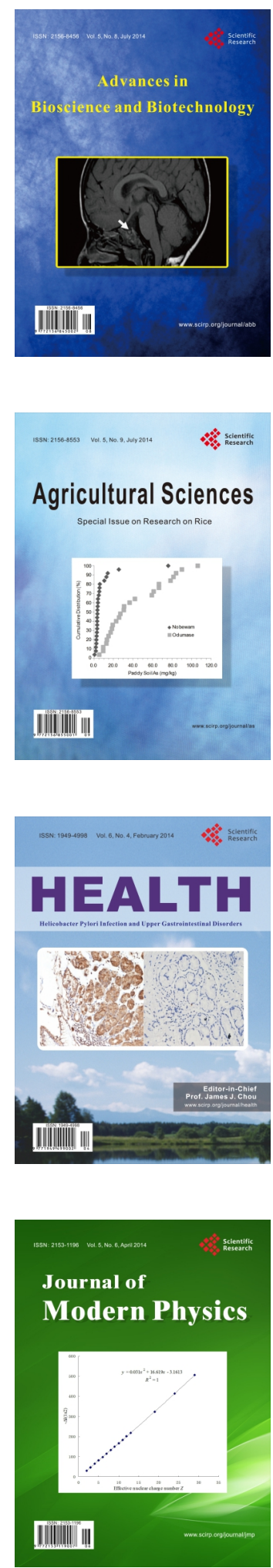
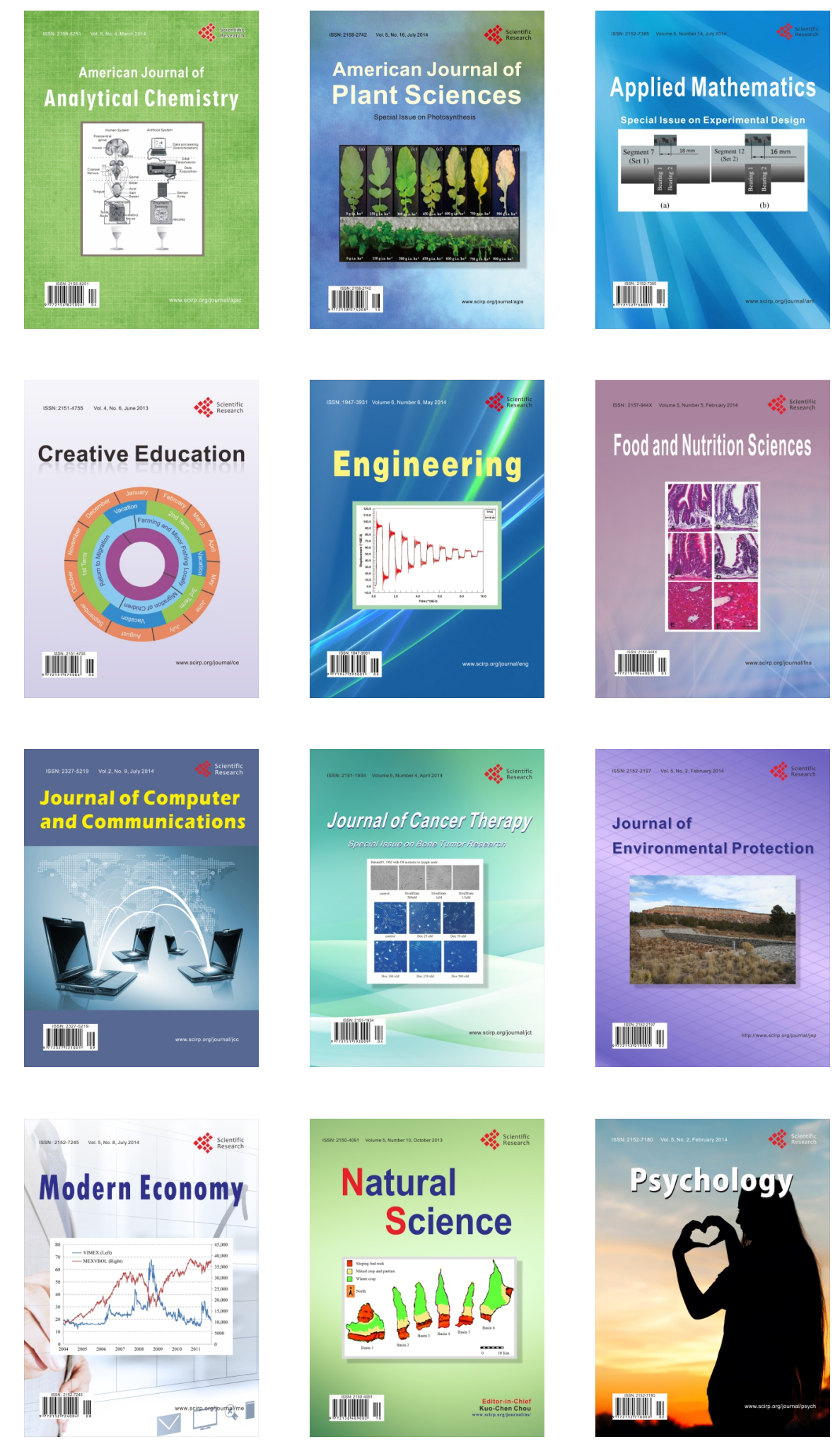